\title{
Chapter 7 \\ Regional Governance and Macroeconomic Crisis Management in Latin America
}

\author{
Maria Antonieta Del Tedesco Lins and Andrea Ribeiro Hoffmann
}

\begin{abstract}
This chapter analyses the governance institutions in Latin America, i.e. norms, instruments and mechanisms designed to deal with macroeconomic and financial crisis management, and their use during the financial crisis which started in 2008 in the USA and reached the region mostly towards the mid-2010s. It argues that Latin American regional institutions never prioritized the harmonization or the development of common macroeconomic policies or mechanisms to deal with financial crises, and the few multilateral initiatives created were not successful.
\end{abstract}

\section{Introduction}

As the 2008 financial crisis evolved, the governments of most countries in the world assessed its potential impact on their domestic stability and adjusted their macroeconomic policies accordingly, complementing or substituting for with various levels of success. Some regions, such as Europe, have had or developed regional governance structures to deal with the crisis collectively, member-states measures given the existence of common regional arrangements, as discussed in several chapters of this volume. In Latin America, most regional organizations did not have or did not develop such structures, and the management of the crisis was handled mainly at the domestic level; the reactions by Argentina, Brazil and Mexico, for instance, are analysed by Lins in Chap. 11 of this volume.

The absence or weakness of common regional structures to deal with external financial crises in Latin America is quite puzzling given that, at the one hand, the region has been fertile for the establishment of regional institutions and structures

\footnotetext{
M. A. D. T. Lins

University of São Paulo (USP), São Paulo, SP, Brazil

e-mail:madtlins@usp.br
}
A. Ribeiro Hoffmann $(\triangle)$
Pontifical Catholic University of Rio de Janeiro (PUC-Rio), Rio de Janeiro, Brazil
Coordinator of the second phase of the Jean Monnet Network "Crisis-Equity-Democracy
for Europe and Latin America", Rio de Janeiro, Brazil
e-mail: a_ribeiro_hoffmann@puc-rio.br


of governance over the years, as discussed by Briceño-Ruiz and Ribeiro Hoffmann in Chap. 18, and, on the other hand, it has been particularly vulnerable to global macroeconomic instability and financial crisis such as in the 1980s and 1990s. This chapter does not explore the reasons for the lack of more robust regional frameworks to respond to financial crisis; rather, it analyses if and how the (few) existing governance institutions played a role in the management of the 2008 crisis (Martins 2017; Kacef and Monti 2010). We argue that, despite the existence of a myriad of regional institutions, the level of cooperation among their member-states and their capacity to act in crisis situations has been extremely limited. It is worth mentioning that most Latin American organizations have norms, instruments and mechanisms in the social areas which were or could have been used to control the damages of macroeconomic instability by compensating for the lost in jobs, revenues and rights, either temporarily or permanently (Medeiros 2016). This chapter does not delve into these governance structures, but we acknowledge their relevance as policy instruments to deal with macroeconomic and financial crisis from a broader perspective.

The chapter is structured in three sections, covering, firstly, the governance structures set by the main regional organizations active during and since 2008 such as Mercosur, UNASUR, ALBA, the Pacific Alliance and CELAC, and secondly, other multilateral institutions such the Corporación Andina de Fomento (CAF) and the Fondo Latinoamericano de Reservas (FLAR), followed by the concluding remarks.

\section{Regional Governance and Economic Crisis Management in Latin America by Regional Organizations}

Despite the enormous variance in terms of issue areas covered and priorities, currently existing regional organizations have practically no norms, instruments and mechanisms to promote the harmonization, cooperation and integration in macroeconomic and financial matters. By the time the 2008 crisis burst, the main organizations active in the region were the key organizations created during the so-called first and second waves of regionalism, i.e. Mercosur, the Andean Community (CAN), the Central American Common Market (CACM) and the Caribbean Common Market (CARICOM), and ALBA, created in 2004 by Cuba and Venezuela to promote a counter-model of regional integration based on the twenty-first Century Socialism. In 2008, UNASUR was created, and soon after, the Pacific Alliance and CELAC (in 2011 and 2012, respectively). UNASUR and CELAC are exemplar of the regional trend in this period, which became to be known as "post-liberal" or "post-hegemonic", given the lack of consensus on free markets as the main motor of regional integration. The Pacific Alliance, instead, must be seen as a reaction to the twenty-first Century Socialism and a regrouping by free-trade countries in the Andean region and Chile. The return to a pro-market approach also led to the creation of Prosur in 2019, but it is too soon to include this organization in the analysis. 
From among organizations, Mercosur and the Pacific Alliance have adopted a more liberal approach to development, even if Mercosur changed over time, as discussed in the already mentioned Chap. 18. UNASUR and CELAC were conceived as broad organizations, covering economic, social and cultural areas, but given their size of membership and diversity of policy preferences of their member-states, they have had a less coherent profile in their economic/development initiatives. One would expect that, independent their of more liberal or more developmentalist profiles, these organizations and their member-states would have an interest in creating buffers against global level instability and external shocks, but this has not been the case. Several reasons are pointed out in the literature, such as asymmetries of domestic macroeconomic indicators, lack of interdependence, political choices and ideologies, but the objective of this chapter is not to explore the causes but rather to map the existing mechanisms and to what extent they were used following the crisis.

Starting with Mercosur, despite many achievements in setting norms and standards, and establishing structures of governance in issue areas such as trade, migration and education, the regulation of services and capital has been a fiasco. The Protocol of Montevideo to foster the integration of financial services, concluded in 1997, entered into force in Brazil and Uruguay in 2019, but it did not play a role so far. Mercosur has actually a bad record in fostering cooperation in macroeconomic and financial matters; the unilateral decision in Brazil to devaluate its currency, the real, without discussing with Mercosur member-states, in 1999, following the contagion of the Asian crisis of 1997, has left a shadow in the region (Bouzas et al. 2002, p. 17-19). When the international liquidity crunch came in 2008, Mercosur countries responded to the crisis according to their domestic priorities, and as a consequence, no common policies were set nor were any specific common interests discussed. Countercyclical policies were effective in Mercosur countries, as all four member-states combined monetary and fiscal policies in order to avoid a heavier fall in consumption and investment than that which the decline in external demand would have originally imposed on their economies. Like in most countries around the world, quite traditional instruments were used: expansion of liquidity, tax exemptions and stimulus to specific sectors and expansion of credit by state-owned financial institutions. Mercosur countries were free from rigid exchange rate policies, even if to very different degrees. A great virtue of the floating exchange rate regime is precisely its ability to absorb external shocks and thus allow the domestic economy to accommodate to the new global situation. This was an important element of the varied reactions of Mercosur countries to the crisis. The four membercountries' exchange rates depreciated in the initial moments of the crisis, but this was followed by quick monetary accommodation. The exception in this case was Argentina who, as a matter of deliberate policy, allowed the peso to continue to depreciate even after the worst period of the crisis had passed. Monetary measures were all devoted to the expansion of liquidity and the reduction of interest rates. In Brazil, federal banks pursed an aggressive increase in the availability of credit through several different instruments according to their specific jobs. Foreign exchange and trade policies were also dictated by the need to protect companies from the shortage in international credit lines. Independently of their relative 
success, the point is that Mercosur member-states did not use the organization as a platform for discussion, coordination or the development of a common approach to handle the crisis.

UNASUR has provided space for a critical discussion about global financial architecture given its more developmentalist profile during the peak days of the "left turn." Meanwhile, Venezuela and Brazil supported the creation of a Bank of the South as an alternative source for the financing of infrastructure to the Bretton Woods institutions and the Inter-American Development Bank (IDB), such as the case of the New Development Bank (NDB) proposed by the BRICS countries in 2014. The Constitutive Act establishing the Bank of the South was signed by Brazil, Bolivia, Argentina, Ecuador, Uruguay, Paraguay and Venezuela in 2007, and the Constitutional Agreement was approved in 2009. The expectation was that it would have a capital of USD 7 bi from the founding members with contributions from Brazil, Argentina and Venezuela (USD 2 bi each), Ecuador and Uruguay (USD 400 mi each), Bolivia and Paraguay (USD $100 \mathrm{mi}$ each), but, unlike the NDB, it was never capitalized, and the project was suspended with the paralysation of Unasur (Calixtre and Barros 2010; Palestini 2016).

ALBA openly promoted a non-capitalist model of regional integration, rejecting free trade and key principles of the capitalist system such as private property and intellectual property. In addition to the oil regime and the creation of Petrocaribe, one of the most ambitious economic initiatives was the creation of a common currency, the Sucre, but to be used mainly as a mechanism of compensation for trade. Cusack argued that although trade via Sucre "grew rapidly from 2010 to 2012, rather than being balanced, this boom consisted largely of Venezuelan imports from Ecuador (...) And beyond 2012, it also became clear that the system was facilitating forms of corruption" (Cusack 2018, p. 127). Benzi (2017, p. 110) also argued that Sucre was undermined by corruption. Venezuela was a partner in $98 \%$ of Sucre trade, and the Venezuelan-Ecuador relationship alone accounted for $89 \%$ of Sucre trade (Cusack 2018, p. 129). Exchange between Cuba and Ecuador, for example, represented just 5.5\% of Sucre Trade in 2016 (Cusack 2018, p. 130). Apart from Sucre, ALBA did not develop any mechanism that could be used to design a common approach to handle with the financial crisis.

The Pacific Alliance was created in 2011 by Chile, Colombia, Mexico and Peru, and its priorities are to foster trade liberalization and establish investment partnerships with Asia, especially China. An innovative initiative in the area of macroeconomics was the creation of the Latin American Integrated Market (MILA), an agreement initially made between the Santiago Stock Exchange, the Colombia Stock Exchange and the Lima Stock Exchange, later joined by Mexico in 2014 to establish a regional market allowing for gains in scale by the trading of stock shares in each of the national markets. ${ }^{1}$ Martins (2017, p.110) argues that by 2015 MILA had not achieved the expected results; the impact of its creation in terms of correlation, risk and profitability was marginal and in terms of volume negotiated

\footnotetext{
${ }^{1}$ https://mercadomila.com/en/who-we-are/our-history/
} 
negative. Even if MILA's record improved since then, this mechanism was not relevant in terms of managing the impact of the 2008 crisis.

Finally, CELAC priorities have not included (macro)economic matters either. Moreover, as Sanahuja argues (Caetano and Sanahuja 2019, p. 31), CELAC can be well defined as another example of summit diplomacy in the region, where presidents have a key say but little interest in institutionalizing common approaches. That said, CELAC has received technical support by CEPAL and SELAC to foster harmonization and the consolidation of regional trade and investment markets (Vadell 2018, p.16), but this process has been hindered by the extreme divergence among its member-states. As highlighted by Bonilla and Jaramillo (2013), CELAC included countries which had very different approaches to trade and macroeconomic policies at the time of its creation, from the (neo)liberal Chile and Peru to (twenty-first century) socialists Venezuela and Cuba, and also countries from the Caribbean, which have also great variation of insertion in the global trade and financial markets. For that reason, it has also been deeply affected by the polarization around the Venezuelan crisis, and its last Presidential Summit took place in 2017, in Punta Cana, Dominican Republic, when only 11 from the 22 presidents were present. ${ }^{2}$ CELAC has also promoted Ministerial Summits, but the last took place in 2015. The third ministerial summit foreseen to take place in 2017 was cancelled. Macroeconomic dialogue was not a priority even during the good times of CELAC, ${ }^{3}$ but this channel was the most appropriate to foster cooperation with the EU (Ghymers discusses a proposal to strengthen this dialogue in Chap. 22 of this volume). In fact, in addition to its role within the region, CELAC has been a platform for the region to dialogue and cooperate multilaterally with partners such as the EU and China. The EU has given special attention to CELAC given its preference to structure its bi-regional relations in formal agreement frameworks. EU-LAC bi-regional relations include Special Partnerships with Brazil and Mexico, bilateral dialogue and/or agreements with individual countries and sub-regions such as the Andean Community, Central American Common Market and Mercosur. ${ }^{4}$

\footnotetext{
${ }^{2}$ http://observatorio.repri.org/artigos/celac-a-retorica-da-integracao/; http://observatorio.repri.org/ artigos/celac-de-1a-convergencia-a-la-paralisis/;http://revistafal.com/ la-celac-en-el-nuevo-escenario-regional/

${ }^{3}$ The Plan of Action approved in 2013 established eight priorities: science, research, innovation and technology; sustainable development; climate change; regional integration and interconnectivity; social cohesion; migration; education; and labor, drugs, gender, investments and entrepreneurship; and the Action plan approved in 2015 added higher education and citizenship security. https:// www.consilium.europa.eu/media/24235/read-the-assessment-of-programmes-and-actions.pdf. See as well http://alcuenet.eu/policy.php

${ }^{4}$ The EU and LAC countries have created a think tank to forward studies about the bi-regional relations, located in Hamburg. https://eulacfoundation.org/en. Veja também https://eeas.europa.eu/ delegations/brazil/48562/rela\%C3\%A7\%C3\%B5es-ue-celac_pt
} 


\section{Other Multilateral Mechanisms to Manage Economic Crisis in Latin America}

A matter of great importance in the debate between nations and as with multilateral institutions since the 1990s emerging economies' financial crises, the struggle to maintain global financial stability has given rise to a series of regional initiatives. The global financial crisis outbreak (2007-2009) reinforced the concern with market stability and brought to the floor the concept of global safety nets (Ocampo 2006; Fritz and Mühlich 2019). Since the establishment of the Chiang Mai Initiative in response to the impacts of the 1997 Asian crisis, a number of collaborative initiatives between regional partners have taken shape.

Although some regional integration initiatives were already present in Latin America, they did not play a decisive countercyclical role in the most recent crisis. Rather, national states have conducted their own stimulus policies taking into account their economic possibilities and political dynamics. Latin America has not been particularly fertile in establishing regional financial arrangements - RFA. When compared to the European and even Asian cases, the few initiatives carried out in Latin America reveal its limited character, both in terms of the extent of participation and in terms of financial collaboration among its members. To fairly look for all possible forms of regional coordination in the face of economic crises, long existing institutions are worth mentioned: the Corporación Andina de Fomento (CAF), the Fondo Latinoamericano de Reservas (FLAR), the Central American Bank for Economic Integration (created in 1961), the Caribbean Development Bank (1969) and the Financial Fund for the Rio de la Plata Basin, FONPLATA (1969) (Garcia 2015). From them, CAF and FLAR - though not bringing together a considerable number of countries in the region - could have played a more integrative role in the face of the crisis.

A veteran institution of financial integration, since it was first created in 1968 by the Andean Group, CAF is formally an Ibero-American development bank. ${ }^{5}$ It has a contingent credit line, and its loan program has broadened to several sectors since the 2000s. However, the characteristics of CAF's financing lines and projects indicate that it operates mainly as a development bank and less as a regional relief fund, even considering its support to sovereign debt issuance and its increasing activities in global markets.

FLAR was created in 1978, by founding members Bolivia, Ecuador, Colombia, Peru and Venezuela. Its functions are typically those of a liquidity fund aimed at supporting countries in the face of problems in their balance of payments through loans and encouraging better management of international reserves, in addition to fostering financial cooperation between partners. Its institutional structure allows the fund to easily incorporate new members, and its very objectives could allow it

${ }^{5} \mathrm{CAF}$ was created in 1970. It is owned by the 17 Latin American and the Caribbean countries and by Spain and Portugal. It has 13 private banks of the region as shareholders. https:/www.caf.com/ en/about-caf/who-we-are/ 
to turn into a powerful Latin American RFA (Lochagin 2015) should the largest economies of the region join. This could also enhance the FLAR's funding capacities.

Given the limited role of formal regional institutions in the region in combating the effects of the global recession, it is interesting to look for other actions carried out jointly by countries in the region to deal with the credit crunch that mastered the late 2000s in global economy. In the absence of regional institutions with macroeconomic cooperation programs, or multilateral financial arrangements or relief funds, some Latin American countries could have possibly established bilateral credit lines or other forms of bailout or mutual aid. The joint issuance of sovereign bonds by Argentina and Venezuela in 2006 - the Bonos del Sur - is an interesting case of credibility borrowing between countries. The markets saw this joint issue as a sign of Argentina's creditworthiness, which eased the country's access to debt financing. Phillips (2013) describes how the three different bonds (two Argentines and one Venezuelan) were initially issued as a package in the primary market but could be traded separately in the secondary market. Although there was no formal guarantee from the Venezuelan government to the Argentine issue, the market evaluated these bonds differently when compared to other Argentine sovereign bonds with similar maturity and yield. This was a very particular case that must be analysed in the perspective of Venezuela's struggle for greater regional leadership, against the backdrop of high availability of resources derived from oil and disputing this leadership with the Brazilian centre-left government.

\section{Concluding Remarks}

This chapter has shown that, despite the plurality and achievements of regional organizations and regional institutions created in Latin America in the past decades, they have never prioritized cooperation and integration on macroeconomic and financial matters. The few existing initiatives such as Mercosur's financial services protocol, UNASUR's Bank of the South, ALBA's common currency Sucre, Pacific Alliance's integration of stock exchanges (MILA) and the Fondo Latinoamericano de Reservas (FLAR) were not used or not effective to buffer the 2008 crisis. Latin American countries handled the impact of the 2008 crisis mainly at the domestic level as they lacked viable mechanisms to react collectively.

\section{Literature}

Benzi, D. (2017). ALBA-TCP. Anatomía de una integración que no fue. Quito: Ediciones Imago Mundi.

Bonilla, A. (2013). In G. Jaramillo (Ed.), La CELAC en el escenario contemporâneo de América Latina y del Caribe. San Jose: FLACSO-CAF. 
Bouzas, R., da Motta Veiga, P., \& Torrent, R. (2002). In-depth analysis of Mercosur integration, its prospectives and the effects thereof on the market Access of EU goods, services and investments. Observatory of Globalization. Barcelona: University of Barcelona.

Caetano, G., \& Sanahuja, J. A. (2019). Integración regional y regionalismo en crisis. Revista uruguaya de Ciencia Política, 28(1), 7-14.

Calixtre, A. B., \& Barros, P. (2010). O Banco do Sul e o Brasil na Agenda da Nova Arquitetura Financeira Regional. IPEA Boletim de Economia e Política Internacional, 3, 22-23.

Cusack, A. K. (2018). Venezuela, ALBA, and the limits of postneoliberal regionalism in Latin America and the Caribbean. New York: Springer.

Fritz, B., \& Mühlich, L. (2019). Regional Financial Arrangements in the Global Financial Safety Net: The Arab Monetary Fund and the Eurasian Fund for Stabilization and Development. Development and Change, 50(1), 96-121.

Garcia, L. E. (2015). Comparative advantages and challenges of Regional Development Banks: THE CAF experience. LSE Global South Unit Policy Brief Series No. 2/2015.

Kacef, O., \& Monti, R. L. (2010). Latin America and the international crisis: Some considerations on macroeconomic policy. The Perspective of the World Review, $2,1$.

Lochagin, G. (2015). A ampliação do Fundo Latino-americano de Reservas como estratégia de integração financeira regional. In E. Iglesias, G. Daminani, A. Garcé, \& F. W. Zibetti (Eds.), Os Desafios da América Latina no Século XXI. São Paulo: Editora da Universidade de São Paulo.

Martins, N. N. (2017). Integração Financeira na América Latina entre 2000 e 2014: avanços, limites e caminhos à frente. Revista Tempo do Mundo, 3, 2.

Ocampo, J. A. (2006). Regional financial cooperation: Experiences and challenges. In J. A. Ocampo (Ed.), Regional financial cooperation (pp. 1-39). Washington, D.C.: Brookings Institution Press.

Palestini, S. (2016). Development banks and regional powers: An analytical framework. KFG Working Paper n.77. Nov. 2016.

Phillips, L. M. (2013). The politics of joint sovereign borrowing: The Venezuelan/Argentine Bono del Sur. Review of International Political Economy, 20(3), 576-604.

Vadell, J. A. (2018). El Foro China-CELAC y el nuevo regionalismo para un mundo multipolar: desafíos para la Cooperación Sur-Sur. Carta Internacional, 13(1).

Open Access This chapter is licensed under the terms of the Creative Commons Attribution 4.0 International License (http://creativecommons.org/licenses/by/4.0/), which permits use, sharing, adaptation, distribution and reproduction in any medium or format, as long as you give appropriate credit to the original author(s) and the source, provide a link to the Creative Commons license and indicate if changes were made.

The images or other third party material in this chapter are included in the chapter's Creative Commons license, unless indicated otherwise in a credit line to the material. If material is not included in the chapter's Creative Commons license and your intended use is not permitted by statutory regulation or exceeds the permitted use, you will need to obtain permission directly from the copyright holder.

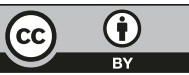

